\title{
Effect of Chilling on Microbiological, Biochemical and Sensory Attributes of Whole Aquacultured Rainbow Trout (Oncorhynchus mykiss Walbaum, 1792)
}

\author{
George Ninan*, Lalitha K.V, Zynudheen A.A and Jose Joseph
}

Central Institute of Fisheries Technology, Kochi 682 029, India

\begin{abstract}
The effect of chilling $\left(0-2^{\circ} \mathrm{C}\right)$ on the quality deterioration of whole ungutted aquacultured rainbow trout (Oncorhynchus mykiss, Walbaum,1792) was studied by integrated evaluations of microbiological, biochemical, and sensory attributes. The counts of aerobic mesophilic, psychrotrophic bacteria and Pseudomonas increased exponentially. An initial lag phase was noticed for $\mathrm{H} 2 \mathrm{~S}$ producing bacteria, Aeromonas and Enterobacteriaceae. Presence of pathogens such as Aeromonas hydrophila and $A$. sobria are of concern in the case of delay in icing or temperature abuse during storage. The $\mathrm{pH}$ values increased from an initial value of 6.74 to 7.13 . PV showed fluctuations. Of the chemical indicators of spoilage, Thiobarbituric acid (TBA) values increased very slowly reaching

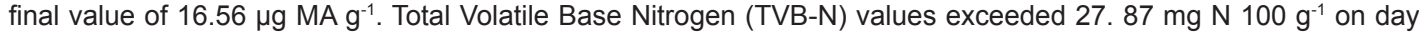
14 when the psychrotrophic counts exceeded $10^{7} \mathrm{cfu} \mathrm{g}^{-1}$ indicating that this value may be useful as a measure of degree of freshness for whole ungutted rainbow trout. Based on the TVB-N and microbiological limits, the shelf life of trout at $0-2^{\circ} \mathrm{C}$ was $9-12$ days.
\end{abstract}

Keywords: Rainbow trout; Chilled storage; Spoilage bacteria, $\mathrm{H}_{2} \mathrm{~S}$ producing bacteria; Volatile bases; Quality; Shelf life

\section{Introduction}

Several species of fresh water fish including common carp (Cyprinus carpio), rohu (Labeo rohita), mrigal (Cirrhinus mrigala) and rainbow trout (Oncorhynchus mykiss) are being farmed in India in order to meet the increasing demand for fresh fish. Among the fresh water fishes, rainbow trout is farmed in many parts of India. Worldwide, farmed trout production is increasing. The demand for trout in the Country is estimated to be $800 \mathrm{~T}$ per annum [1]. Rainbow trout (Oncorhynchus mykiss Walbaum), an exotic cold water species, is considered to be a highly priced fish in India. The fish is marketed mainly as fresh in chilled condition. Recently it was found its way to supermarkets in metro cities as an exotic food item which has demand among the urban population. Trout fillets in the form of smoked and vacuum packaged products have high demand in northern European countries. Trout is a preferred table fish in the U.S and Europe. The increasing demand for high quality fresh seafood has intensified the search for methods and technologies for better utilization of fresh fish.

The quality of fresh fish is a major concern to the consumers and industry. Fish is extremely perishable and the shelf life of such products is limited in the presence of normal air by the chemical effect of atmospheric oxygen and the growth of aerobic spoilage microorganisms. It is generally accepted that the environment can influence the microflora associated with the skin, gills and intestines of finfish [2]. Therefore, fish grown in different aquaculture systems may harbour different numbers and species of bacteria. The culture practices such as pond fertilization, supplementary feeding with slaughter house waste or agricultural byproducts imposes a high probability of contamination on the aquacultured fish. Types and levels of bacterial populations associated with farmed fish are useful indicators of quality and safety of fish. Interaction between microbial metabolism and physic-chemical reactions accelerate fish quality deterioration as amines formation, lipid, nucleotide and protein degradation contributes to off odours, off flavours and texture softening [3,4] Pseudomonas spp. and $S$. putrefaciens are the specific spoilage bacteria of marine and freshwater tropical fish stored in ice [5].

Although quality attributes of farmed rainbow trout from temperate counties were evaluated by many workers [6-11], few carried out quality assessment of tropical freshwater fish species [12]. Dawood et al. [13] reported a rapid deterioration in quality of headed and gutted rainbow trout (Salmo gairdneri) over a 14 day period of storage when fish had been held at high ambient temperature $\left(30^{\circ} \mathrm{C}\right)$ for $6 \mathrm{~h}$. Studies indicated the shelf life of rainbow trout as two weeks for gutted fish in ice [8], 15-16 days for whole ungutted fish, 10-12 days for fillets stored in ice [12] and 6 days for gutted vacuum packed and refrigerated samples [14].

With the increase in aquaculture of this species in India, it is important to study the storage capacity of fish under refrigerated condition following harvest. Due to the perishable nature of fish, there is an obvious need for development of efficient preservation methods, which allow shelf life extension of these products. However, collective works on various quality aspects (chemical, microbiological, textural and sensory) of trout of tropical region stored in ice are scarce. The objective of this study was to assess the quality of farmed rainbow rout stored in ice and kept at chilled condition by integrated evaluations of sensory, microbiological and biochemical attributes and to understand

*Corresponding author: George Ninan, Senior Scientist, Fish Processing Division, Central Institute of Fisheries Technology (ICAR), Kochi 682 029, India, E-mail: george66jiji@rediffmail.com

Received June 24, 2011; Accepted October 18, 2011; Published November 08, 2011

Citation: Ninan G, Lalitha KV, Zynudheen AA, Joseph J (2011) Effect of Chilling on Microbiological, Biochemical and Sensory Attributes of Whole Aquacultured Rainbow Trout (Oncorhynchus mykiss Walbaum, 1792). J Aquac Res Development S5:001. doi:10.4172/2155-9546.S5-001

Copyright: ( 2011 Ninan G, et al. This is an open-access article distributed under the terms of the Creative Commons Attribution License, which permits unrestricted use, distribution, and reproduction in any medium, provided the original author and source are credited. 
Citation: Ninan G, Lalitha KV, Zynudheen AA, Joseph J (2011) Effect of Chilling on Microbiological, Biochemical and Sensory Attributes of Whole Aquacultured Rainbow Trout (Oncorhynchus mykiss Walbaum, 1792). J Aquac Res Development S5:001. doi:10.4172/2155-9546.S5-001

Page 2 of 8

the spoilage microflora to develop efficient preservation methods which allow extension of shelf life.

\section{Materials and Methods}

\section{Material}

Rainbow trout (O.mykiss) of average weight $250 \mathrm{~g}$ and average length $278 \mathrm{~mm}$ were obtained from aquaculture farm located at Rajamallay near Munnar in the High Ranges in Southern India. It was harvested by aggregating into a corner of the pond and scooped by two persons using a drag net. The fish were killed by immersing in ice-cold water (hypothermia), and transported to the laboratory within $6 \mathrm{~h}$ of harvesting, in insulated polystyrene boxes containing ice. On reaching the laboratory the whole fish samples were repacked with flake ice (ice/ fish ratio 1:1) in polystyrene boxes, provided with outlets for water drainage and stored in a chilled room at a temperature of 0 to $2^{\circ} \mathrm{C}$. The ice/fish ratio was maintained constant throughout the experiment. Ten randomly chosen fish were removed from ice after $0,3,6,9,12,14$ and 15 days for analysis

\section{Microbiological analysis}

Twenty five gram muscle with skin were aseptically weighed and homogenized with $225 \mathrm{ml}$ sterile physiological saline for 60s. in a stomacher (Lab Blender 400; Seward Medical, Norfolk, IP24, IXB, UK). The homogenates were serially diluted and $0.5 \mathrm{ml}$ of appropriate serial dilutions was plated on the surface of appropriate media in duplicate by spread plate method and then incubated. For mesophilic and psychrotrophic bacteria, tryptic soy agar plates (TSA, Oxoid, U.K.) were used and plates were incubated at 37 and $7^{\circ} \mathrm{C}$ for 2 and 10 days respectively [15,16]. Pseudomonas were counted on Cetrimide-FusidinCephaloridine (CFC) agar (Oxoid code CM 559, supplemented with SR 103; Oxoid U.K.) after 3 days incubation at $20^{\circ} \mathrm{C}$. [17,18]. Aeromonas spp. were counted on starch ampicillin (SA) agar (Hi Media, India) containing $10 \mathrm{ug} / \mathrm{ml}$ of ampicillin incubated at $28^{\circ} \mathrm{C}$ fir $48 \mathrm{~h}$. [19]. Brochothrix thermosphacta was determined on Streptomycin sulfateThallous acetate - Actidione Agar (STAA Hi Media, India) after incubation at $20^{\circ} \mathrm{C}$ for 4 days [20].

Enterobacteriaceae and $\mathrm{H}_{2} \mathrm{~S}$-producing bacteria (including Shewanella putrefaciens) were counted on violet red bile glucose agar (VRBGA, Oxoid code CM 485) and Iron Agar (IA, Oxoid code CM $867)$, respectively by pour plate method and plates were incubated respectively at $30^{\circ} \mathrm{C}$ for $24 \mathrm{~h}$. [21] and $20^{\circ} \mathrm{C}$ for 5 days [22].

Faecal Streptococci and Staphylococcus aureus counts were determined respectively on KF Streptococci Agar (Oxoid code CM 701) after incubation at $37^{\circ} \mathrm{C}$ for 2 days and on Baird Parker Agar (Oxoid code CM 275) incubated at $37^{\circ} \mathrm{C}$ for 2 days and typical colonies were confirmed [23]. Total coliforms, faecal coliforms and Escherichia coli were estimated by the three tube MPN method [24].

The dominant aerobic microflora at the final sampling points was determined by isolating and identifying $20 \%$ of the colonies from PCA $\left(30\right.$ and $7^{\circ} \mathrm{C}$ ) plates. $20-25$ colonies were randomly selected from PCA plates. A total of 112 bacterial cultures were isolated from fresh and ice stored trout. Fifty two colonies were picked from PCA plates $\left(30^{\circ} \mathrm{C}\right)$ sampled from the fresh prawn and identified. To identify spoilage flora, 60 colonies were randomly selected from PCA $\left(7^{\circ} \mathrm{C}\right)$ plates poured on the day fish were considered unacceptable (sensory score 6) and characterized morphologically and bio-chemically. A 5-8 black colonies each were isolated and characterized from IA, VRBGA and SA agar plates at the final sampling points. They were then grouped according to the taxonomic schemes proposed by several authors for identification (Dainty et al. [25]; Molin and Ternstorm [17]; Krieg and Holt [26]; Sneath et al. [27]; Kirov [28]; Brenner et al. [29]). The isolated cultures were identified and confirmed using API 20NE and API 20NE system (Biomerieux, France).

\section{Biochemical analysis}

Moisture, ash and total nitrogen and total fat content were determined using AOAC methods N. 950.46B, 920.153, 928.08 and 960.39 of AOAC, [16] respectively. $\mathrm{pH}$ was measured in fish homogenates ( $10 \mathrm{~g}$ of fish per $10 \mathrm{ml}$ of distilled water) with a Cyberscan $510 \mathrm{pH}$ meter (Eutech Instruments, Singapore). Thiobarbituric acid (TBA) value was determined according to the method of Tarladgis et al. [30] by mixing $10 \mathrm{~g}$ of fish meat with $100 \mathrm{ml} .0 .2 \mathrm{~N} \mathrm{HCl}$. TBA value was calculated and expressed in $\mu \mathrm{g}$ malonaldehyde / $\mathrm{g}$ of fish sample. Total Volatile Base Nitrogen (TVBN) and Trimethyl amine (TMA) was determined in triplicate by the micro diffusion method [31] from the trichloro acetic acid extract of the muscle. TMA-N and TVB-N was calculated and expressed in $\mathrm{mg} / 100 \mathrm{~g}$ of the sample. Peroxide Value (PV) and Free Fatty Acid (FFA) were determined according to Jacobs [32] and AOCS [33] respectively.

\section{Sensory analysis}

Sensory analysis of whole trout stored in ice were performed during storage by a ten member trained sensory panel composed of the staff from the laboratory. While drawing the samples for sensory evaluation, special attention was given to check any change in colour or odour The panel assessed different attributes like appearance, odour, flavour and texture. The overall acceptance was determined by evaluating the attributes like odor, taste and texture of whole cooked fish (cooking steaks in boiling water containing $2 \%$ salt for two minutes) Each sample of the lot was classified using a 10 point hedonic scale, 4 being the acceptability limit.

Sensory analysis of whole trout was performed during iced storage according to the European Community (EC) grading scheme by ten trained panelists [34]. The panel assessed different attributes like appearance, odour, flavour and texture. The appearance of the skin, eyes, gills and internal organs, surface slime, and the odor and texture of each fish (whole) was assessed into four quality grades - excellent quality (perfect condition, E), high quality (slight loss of excellent characteristics, A), good quality (some deterioration, but fit for sale, B) and unfit for sale ( C). Color analysis was performed with a Hunter lab Miniscan ${ }^{\circledR}$ XE plus spectrocolorimeter (Hunter Associates Laboratory, Inc. Reston, Virginia, USA). Measurements were recorded using the $\mathrm{L}^{\star}$ $\mathrm{a}^{\star} \mathrm{b}^{\star}$ colour scale [35]. Chroma $\left(\mathrm{C}^{\star}\right)$ and Hue $\left(\mathrm{h}^{\star}\right)$ also were calculated from the $\mathrm{L}^{*} \mathrm{a}^{*} \mathrm{~b}^{*}$ values. Three repetitions of the different colour parameters were recorded.

\section{Statistical analysis}

Experiments were replicated twice on different occasions with fish samples from the same farm. Results are presented as mean \pm standard deviation and significance of the differences between the mean values was determined by One-way Analysis of Variance (ANOVA), followed by Duncan's test using SPSS software (version 10.0) for Windows. $p$-value lower than 0.05 was considered statistically significant.

\section{Results and Discussion}

Aerobic mesophilic and psychrotrophic bacteria grew exponentially from an initial load of 3-5 $\log _{10} \mathrm{cfu} \mathrm{g}^{-1}$ reaching $7.6 \log _{10} \mathrm{cfu} \mathrm{g}^{-1}$ on day 15 (Figure 1). The initial mesophilic bacterial load of $4.7 \log _{10} \mathrm{cfu} \mathrm{g}^{-1}$ 


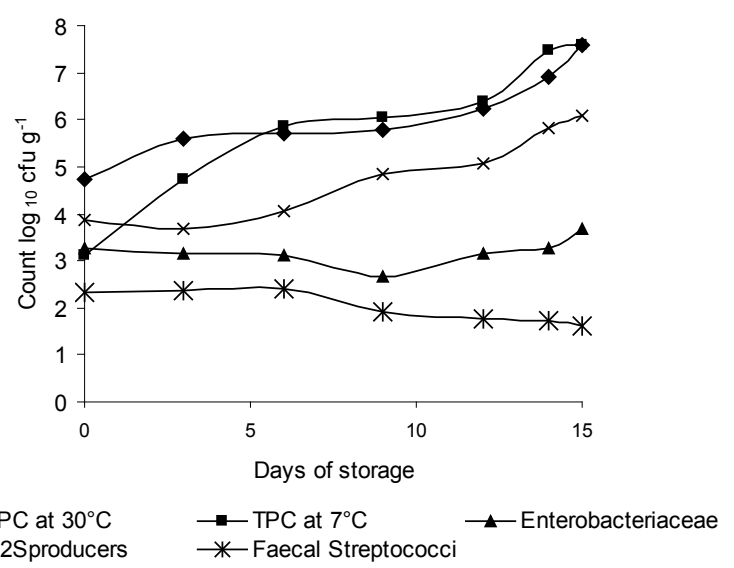

Figure 1: Changes in the population of aerobic mesophilic, bacteria, psychrophic bacteria, H2S producing bacteria, faecal streptococci and Enterobacteriaceae in trout stored at $0-2^{\circ} \mathrm{C}$.

indicated good quality of trout as it ranged from 2-6 $\log _{10} \mathrm{cfu} \mathrm{g}^{-1}$. [36]. These values obtained in this study are close to the values reported earlier for aquacultured fresh trout from Spain [37,41], Greece [38, 39] and U.K [40]. It is widely accepted that the initial microbial load of fresh water varies depending on water conditions and temperature. The initial and final aerobic mesophilic bacterial associations of trout stored in ice were found to be similar to those reported in the literature for trout stored aerobically.

In this study, mesophilic and psychrotrophic counts in fresh fish tissues were close to or lower than the m value $(5 \times 105 \mathrm{cfu} / \mathrm{g})$ recommended by the International Commission of Microbiological Specification for Foods [42] for whole fresh water fish. Taking the 107 $\mathrm{cfu} \mathrm{g}^{-1}$ psychrotrophic count as the spoilage level, the shelf life of chilled stored trout in this study was 9-12 days as reported earlier by Fik and Surówka [43] and Rezaei et al. [44]. For fresh fish, the microbiological limit (M) for human consumption proposed by ICMSF [42] is 107cfu $\mathrm{g}^{-1}$.

Of the bacterial groups examined in the present study, H2Sproducing bacteria had the highest counts followed by Pseudomonas spp., Aeromonas, B. thermosphacta and Enterobacteriaceae (Figures $1 \& 2$ ). H2S producing bacterial counts constituted $<5 \%$ of the total flora in fresh trout $\left(3.8 \log _{10} \mathrm{cfu} \mathrm{g}^{-1}\right)$, their levels increased significantly $(\mathrm{P}<0.01)$ during storage and its proportion in the total flora reached $10-15 \%$ at the end of storage indicating their role in the spoilage. H2S producing bacteria were identified as Shewanella and Aeromonas. Pseudomonas displayed the typical growth pattern of psychrotrophic bacteria without a lag phase (Figure 1) increasing from initial counts of 3.0 to $5.02 \log _{10} \mathrm{cfu} \mathrm{g}^{-1}$ on day 15 . These two bacterial groups were found to be the specific spoilage organism (SSO) in fish from temperature and tropical waters [5]. Shewanella spoilage is characterized by TMA and sulphides (H2S) whereas the Pseudomonas spoilage is characterized by absence of these compounds and occurrence of sweet, rotten sulphydryl odours. Pseudomonas and Shewanella isolates produced large amounts of TVBN, secreted huge amounts of proteolytic enzymes and intense off-odours and were identified as strong spoiling bacteria. Chytiri et al. [12] also reported dominance of Pseudomonas, H2S producing bacteria (including Shewanella putrefaciens) and B. thermosphacta in the spoilage microflora of whole ungutted and filleted trout over an 18 day storage period in ice.
Aeromonas was also found to be members of the microflora of farmed trout with an initial load of $3.18 \log _{10} \mathrm{cfu} \mathrm{g}^{-1}$ as reported earlier by Nam and Joh [45]. A reduction in bacterial load was noticed during the first week of iced storage and growth was resumed after 12 days (Figure 2). Aeromonas isolates were identified as A. hydrophila and A. sobria. These bacterial species produced proteinases, reduced TMAO and produced off-odours indicating their spoilage potential. Although these bacteria are capable of growth at chill temperatures, they required a period of adaptation (i.e., the lag phase and slow growth phase) in this study. Lee et al.[46] isolated A. hydrophila from diseased trout from Korea and this bacterium is responsible for hemorrphagic septicemia, a disease affecting a wide variety of freshwater and marine fish [47]. Epizootic Ulcerative syndrome caused by A. sobria resulted in great damage to fish farms in Bangladesh and India [48]. Gonzalez et al.[49] noticed the strong potential spoilage activity of aeromonads in wild and aquacultured iced freshwater fish. A. hydrophila, A. veronii biovar veronii and A. veronii biovar sobria are the strains more often associated with gastroenteritis in humans and the enteropathogenic potential of these strains were comparatively high when grown at low temperatures than at $37 \mathrm{oC}[50,51]$. The occurrence of A. hydrophila and A. sobria in trout farms and ice stored trout must be taken into consideration because it can cause gastroenteritis and wound infections. The ability of these organisms to grow at refrigeration temperatures indicates the potential food safety issues from such foods.

Brochothrix thermosphacta population in ice stored trout increased from an initial count of $2.32 \log _{10} \mathrm{cfu} \mathrm{g}^{-1}$ to $3.9 \log _{10} \mathrm{cfu} \mathrm{g}^{-1}$ (Figure 3). Similar counts for whole ungutted trout were reported by Chytiri et al. [12] on day 15 in iced storage.

Enterobacteriaceae were also part of the microflora of farmed rainbow trout which is in agreement with the findings of Arashisar et al. [10], Chytiri et al. [12] and Nerantzaki et al.[39] . Enterobacteriaceae counts decreased during the first week of storage from an initial value of $3.2 \log _{10} \mathrm{cfu} \mathrm{g}^{-1}$. At the end of storage, a count of $3.66 \log _{10} \mathrm{cfu} \mathrm{g}^{-1}$ was noticed. The dominant species identified in this study were Citrobacter freundii, Hafnia alvei and Pantoea agglomerans. In this study, Enterobacteriaceae were found in high numbers in fresh trout and their

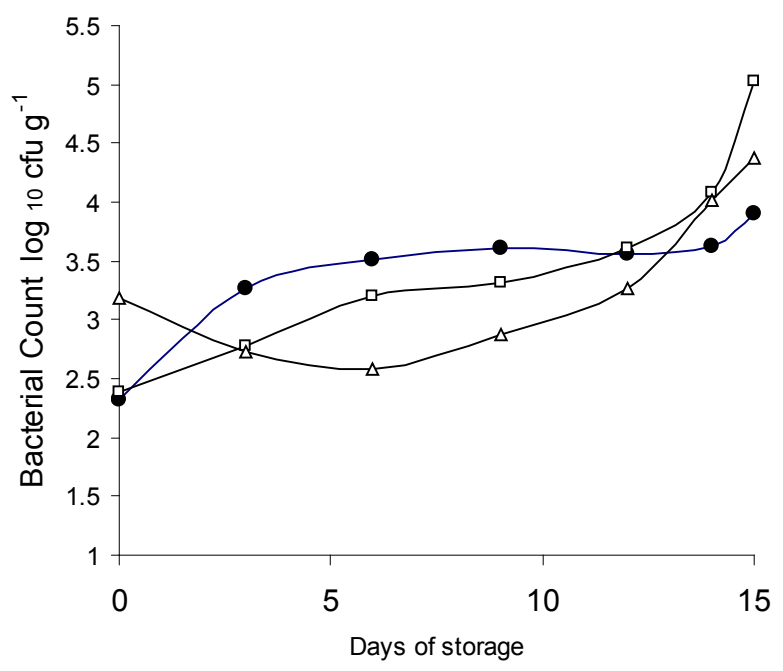

$\longrightarrow$ B thermosphacta $\longrightarrow-$ Pseudomonas $\neg-$ Aeromonas

Figure 2: Changes in Aeromonas, Pseudomonas and B. themosphacta population in trout stored at $0-20 \mathrm{C}$. 
abundance decreased during ice storage, possibly because of their lower growth rate than that of other Gram-negative psychrotrophic spoilers. The contribution of Enterobacteriaceae to the microflora of trout and its potential to cause spoilage must be taken into consideration in case of delay in chilling after catch or temperature abuse during storage.

Among the indicator organisms, faecal streptococcal population was $2.3 \log 10 \mathrm{cfu} \mathrm{g}^{-1}$ initially and at the end of storage the count was ca. $1.6 \log 10 \mathrm{cfu} \mathrm{g}^{-1}$ (Figure 1). S. aureus numbers were low (1.3 log $10 \mathrm{cfu}$ $\left.\mathrm{g}^{-1}\right)$ in fresh trout and were within the acceptable limit. S. aureus were not detected in trout during iced storage. Icing affected populations of total coliforms, Faecal coliforms and E. coli levels (Figure 3) and 1-2 $\log$ reduction was noticed. E. coli counts in trout on day $3\left(<6 \mathrm{~g}^{-1}\right)$ was below the $\mathrm{m}$ limit (11 g -1) recommended by the ICMSF [42]) for good quality fish. High levels of faecal coliforms were previously reported for fish farms in India [52-54].

A total of 52 strains were isolated from $30^{\mathrm{C}} \mathrm{PCA}$ plates and identified. In fresh trout, majority of the isolates (70\%) were gram-negative rods. The main bacterial groups identified among the 52 isolates randomly selected from TSA plates were i. Gram-negative aerobic coccobacilli and rods (Moraxella, Acinetobacter, Flavobacterium), ii. Gram-negative aerobic motile rods (Pseudomonas), iii.Enterobacteriaceae (Enterobacter, Citrobacter, Hafnia, Klebsiella), iv. Aeromonadaceae (Aeromonas), v. Micrococcaceae ( Kocuria, Staphylococcus) andvi.Gram-positive spore forming bacteria (Bacillus). González et al. [41] reported predominance of Acinetobacter, Pseudomonas, Staphylococcus, Enterococcus and Bacillus in rainbow trout from Spain. On icing, the abundance of Enterobacteriaceae decreased. A total of 56 strains were characterized from $30^{\mathrm{C}}$ PCA plates. The majority $(>60 \%)$ of the trout isolates after 15 days in ice belonged to genera Moraxella, Acinetobacter, Pseudomonas, Shewanella, Aeromonas and Flavobacterium indicating that spoilage of fresh trout stored aerobically is due to the activity of more than one specific spoilage organism. Flavobacterium have been found in other

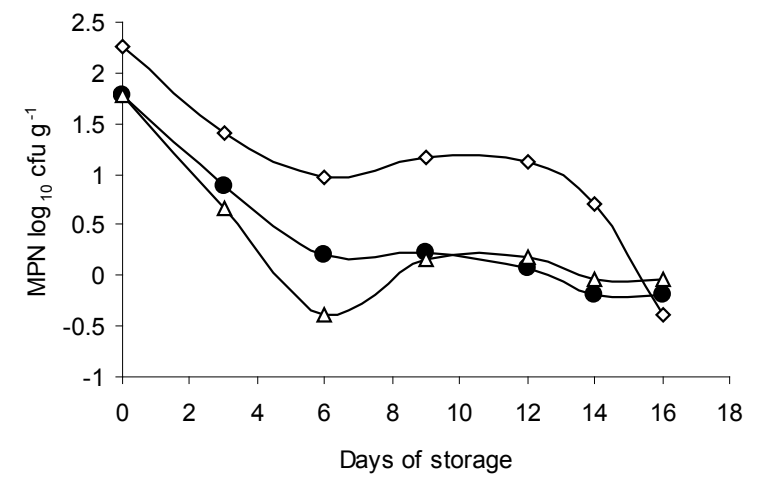

$\prec$ total coliforms

- faecal coliforms

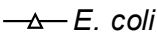

Figure 3: Changes in total coliform, faecal coliform and E coli population in trout stored at $0-2^{\circ} \mathrm{C}$

\begin{tabular}{|l|l|l|l|l|}
\hline DAYS & Moisture $(\%)$ & Protein $(\%)$ & Fat $(\%)(\mathrm{dwb})$ & Ash (\%) \\
\hline 0 & $78.04 \pm 0.31$ & $19.80 \pm 0.65$ & $1.60 \pm 0.12$ & $0.61 \pm 0.23$ \\
\hline 3 & $79.06 \pm 0.41$ & $19.18 \pm 0.82$ & $1.56 \pm 0.05$ & $0.66 \pm 0.04$ \\
\hline 6 & $79.12 \pm 0.23$ & $19.06 \pm 0.56$ & $1.54 \pm 0.06$ & $0.64 \pm 0.07$ \\
\hline 9 & $79.41 \pm 0.32$ & $18.48 \pm 0.77$ & $1.57 \pm 0.14$ & $0.66 \pm 0.04$ \\
\hline 12 & $79.73 \pm 0.45$ & $18.09 \pm 0.54$ & $1.47 \pm 0.09$ & $0.72 \pm 0.06$ \\
\hline 14 & $80.24 \pm 0.42$ & $18.06 \pm 0.56$ & $1.45 \pm 0.04$ & $0.65 \pm 0.04$ \\
\hline 15 & $80.64 \pm 0.11$ & $17.97 \pm 0.28$ & $1.42 \pm 0.04$ & $0.61 \pm 0.03$ \\
\hline
\end{tabular}

Table 1: Proximate composition of trout stored at $0-20 \mathrm{C}(\mathrm{n}=3 \times 2)$. farmed fish species such as catfish and some are also the causative agent of bacterial cold water disease and rainbow trout fry syndrome $[55,56]$. Several investigations have concluded that Gram- negative rod-shaped bacteria (e.g., Pseudomonas, Moraxella and Acinetobacter) dominate on many fish caught in tropical waters [36,57].

Results of proximate analysis of whole ungutted trout stored at 0 -2 0C during the 15-day storage are given in Table 1 . Raw trout is a fish with a fat content of $1.60 \pm 0.12 \mathrm{~g} / 100 \mathrm{~g}$ edible meat, a protein content of $19.80 \pm 0.65 \mathrm{~g} / 100 \mathrm{~g}$ edible meat and ash content of $0.61 \pm 0.23$ $\mathrm{g} / 100 \mathrm{~g}$ edible meat. The levels of fat and ash were low compared to that reported for trout from other regions [58-60,41]. During storage in ice, no significant variations in the composition of major constituents viz. moisture, protein and fat were observed. A slight increase of $3.33 \%$ moisture content was observed after 15 days in chilled storage. The retention of good texture of fish muscle during chilled storage can be attributed to the minimum leaching of the major constituents and low water penetration into the flesh.

The changes in TVB-N and TMA levels in whole trout throughout the storage in ice are shown in Table 2. The results of this study confirmed the earlier studies of Rodriguez et al. [61] and Chytiri et al. [12] who reported TMA values of $\leq 1.0 \mathrm{mg} / 100 \mathrm{~g}$ for whole fresh trout and values of $\leq 3.0 \mathrm{mg} / 100 \mathrm{~g}$ on day 15 for ice stored fish indicating the low level of trimethylamine oxide (TMAO) in the flesh of this fish species. TMAO quantity in fish varies with the species and the environment. A wide range of TMA-N values have been reported by several investigators as acceptability limit i.e., 1-5mg N/100 g [62- 65]. Sikorski et al. [66] and Dalgaard et al. [67] reported that a population of 108-109 cfu/g of $S$. putrefaciens was considered crucial for TMA production. In this study, the count of $\mathrm{H} 2 \mathrm{~S}$ - producing bacteria (including $S$. putrefaciens) was low $(6.07 \log \mathrm{cfu} / \mathrm{g})$ at the end of iced storage which could be the reason for low levels of TMA.

TVBN, including trimethylamine, dimethylamine, ammonia and other volatile basic nitrogen compounds, was produced mainly by bacterial decomposition of fish flesh. In this study, TVB-N levels

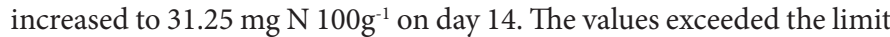

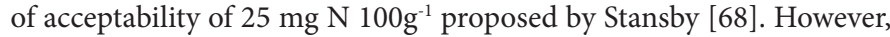
fish were acceptable based on sensory score and microbiological counts. Critical limits of 25,30 and $35 \mathrm{mg} \mathrm{N} \mathrm{100g}^{-1}$ of TVB-N were established for different groups of fishes [69]. However, no limit for acceptability has been established for rainbow trout. Hence, based on the TVB-N levels, microbiological counts and spoilage indicators, TVB-N limit

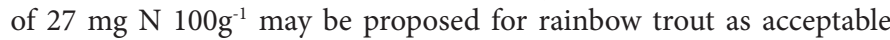
limit. As TMA production was low, ammonia probably accounted for the major portion of volatile bases. Giménez et al. [9] observed TVB-N value of $35 \mathrm{mg} \mathrm{N} 100 \mathrm{~g}^{-1}$ in trout fillet stored under air on day 8 and reported good correlation with bacterial counts $\left(108 \mathrm{cfu} \mathrm{g}^{-1}\right)$.

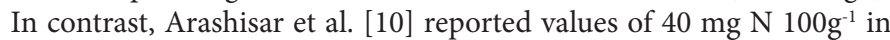
filleted trout at the end of 14 days storage. However, the values were < $20 \mathrm{mg} \mathrm{N} 100 \mathrm{~g}^{-1}$ when psychrotrophic bacterial levels exceeded $107 \mathrm{cfu}$ $\mathrm{g}^{-1}$ on day 6 at $4 \pm 1^{\circ} \mathrm{C}$. There is good correlation between TVB-N and microbiological parameters in the present study as reported earlier by Katikou et al. [70]. The results also suggest that since TVBN values exceeded limit of acceptability on day 14 when fish had a stale order, it may be useful as a measure of degree of freshness; although some reports differ in this context $[71,12]$.

While evaluating the spoilage potential of nine bacterial groups isolated from cold smoked salmon, Stohr et al. [72] have reported that Gram negative bacterial strains such as Aeromonas, Shewanella and Serratia produced TMA in concentrations ranging from 11.0 to $13.1 \mathrm{mg}$ 
Citation: Ninan G, Lalitha KV, Zynudheen AA, Joseph J (2011) Effect of Chilling on Microbiological, Biochemical and Sensory Attributes of Whole Aquacultured Rainbow Trout (Oncorhynchus mykiss Walbaum, 1792). J Aquac Res Development S5:001. doi:10.4172/2155-9546.S5-001

Page 5 of 8

\begin{tabular}{|c|c|c|c|c|c|c|}
\hline Days & $\begin{array}{l}\mathrm{PV} \\
\left(\text { meq } \mathrm{O}_{2} / \mathrm{Kg}\right)\end{array}$ & $\begin{array}{l}\text { TBA } \\
(\mu \mathrm{g} M A / g)\end{array}$ & $\begin{array}{l}\text { FFA } \\
\text { (mg \% oleic acid) }\end{array}$ & $\begin{array}{l}\text { TMA } \\
(\mathrm{mg} / 100 \mathrm{~g})\end{array}$ & $\begin{array}{l}\text { TVB-N } \\
(\mathrm{mg} \mathrm{N} / 100 \mathrm{~g})\end{array}$ & $\mathrm{pH}$ \\
\hline 0 & ND & $4.97 \pm 0.27^{a}$ & $3.28 \pm 0.26^{a}$ & $1.23 \pm 0.11^{\mathrm{a}}$ & $14.6 \pm 0.26^{a}$ & $6.77 \pm 0.03^{a}$ \\
\hline 3 & $9.11 \pm 0.08^{a}$ & $4.5 \pm 0.1^{b}$ & $2.92 \pm 0.04^{b}$ & $1.5 \pm 0.1^{b}$ & $19.67 \pm 0.29$ b & $6.75 \pm 0.02^{a}$ \\
\hline 6 & $5.34 \pm 0.42^{b}$ & $9.55 \pm 0.11^{c}$ & $2.33 \pm 0.09^{c}$ & $1.6 \pm 0.2 \mathrm{bc}$ & $19.73 \pm 0.46^{b}$ & $7.03 \pm 0.04^{b}$ \\
\hline 9 & $3.48 \pm 0.35^{c}$ & $14.14 \pm 0.16^{d}$ & $2.95 \pm 0.01^{b}$ & $1.71 \pm 0.03^{b c}$ & $21.08 \pm 0.16^{c}$ & $7.12 \pm 0.01^{c}$ \\
\hline 12 & $4.62 \pm 0.17^{d}$ & $15.47 \pm 0.06^{e}$ & $3.4 \pm 0.36^{a}$ & $1.68 \pm 0.03^{b c}$ & $27.87 \pm 0.26^{d}$ & $7.14 \pm 0.03^{c}$ \\
\hline 14 & $5.82 \pm 0.28^{b}$ & $16.2 \pm 0.36^{f}$ & $2.81 \pm 0.10^{b}$ & $1.79 \pm 0.07^{c}$ & $31.25 \pm 0.15^{\mathrm{e}}$ & $7.14 \pm 0.02^{c}$ \\
\hline 15 & $8.4 \pm 0.35^{\mathrm{e}}$ & $16.56 \pm 0.47^{f}$ & $3.93 \pm 0.05^{d}$ & $3.32 \pm 0.13^{d}$ & $31.20 \pm 0.44{ }^{e}$ & $7.13 \pm 0.03^{c}$ \\
\hline
\end{tabular}

*Within each column, means with the same superscript do not differ significantly $(p>0.05)$.

Table 2: Changes in Peroxide Value (PV), Thiobarbituric Acid value (TBA), Trimethyl amine (TMA), Free Fatty Acid value (FFA), Total Volatile Nitrogen (TVB-N) and pH of trout stored at $0-20 C^{*}(n=3 \times 2)$

\begin{tabular}{|c|c|c|c|c|c|c|}
\hline Days & Skin & Eyes & Gills & Flesh colour & Outer slime & EC Grade \\
\hline 0 & Bright, shining ; firm & $\begin{array}{l}\text { Translucent cornea; } \\
\text { convex; absence } \\
\text { mucus }\end{array}$ & $\begin{array}{l}\text { Fresh odor; } \\
\text { red color }\end{array}$ & Pinkish white & $\begin{array}{l}\text { thin; } \\
\text { transparent }\end{array}$ & $E$ \\
\hline 3 & Bright shining; firm & $\begin{array}{l}\text { Translucent cornea; } \\
\text { convex; absence } \\
\text { mucus }\end{array}$ & $\begin{array}{l}\text { Fresh odor; } \\
\text { red color }\end{array}$ & Pinkish white & $\begin{array}{l}\text { thin; } \\
\text { transparent }\end{array}$ & $E$ \\
\hline 6 & Bright shining; firm & $\begin{array}{l}\text { Translucent cornea; } \\
\text { convex; absence } \\
\text { mucus }\end{array}$ & Fresh odor; red color & Pinkish white & $\begin{array}{l}\text { thin; } \\
\text { transparent }\end{array}$ & $E$ \\
\hline 9 & $\begin{array}{l}\text { Waxy; slight loss of } \\
\text { shine; soft }\end{array}$ & $\begin{array}{l}\text { Opalescent cornea; } \\
\text { plane; moderate } \\
\text { mucus }\end{array}$ & $\begin{array}{l}\text { Fishy odor; } \\
\text { red color }\end{array}$ & Whitish & Aqueous; transparent & A \\
\hline 12 & $\begin{array}{l}\text { Waxy; slight loss of } \\
\text { shine; soft }\end{array}$ & $\begin{array}{l}\text { Opalescent cornea; } \\
\text { plane; moderate } \\
\text { mucus }\end{array}$ & $\begin{array}{l}\text { Stale odor; } \\
\text { dark red color }\end{array}$ & Whitish & $\begin{array}{l}\text { Opaque; thick; } \\
\text { slight milky }\end{array}$ & B \\
\hline 14 & Dull; some bleaching & $\begin{array}{l}\text { Opalescent cornea; } \\
\text { plane; excessive } \\
\text { mucus }\end{array}$ & $\begin{array}{l}\text { Stale odor; dark red } \\
\text { color }\end{array}$ & $\begin{array}{l}\text { Whitish with slight yel- } \\
\text { low stain }\end{array}$ & $\begin{array}{l}\text { Opaque; thick; } \\
\text { slight milky }\end{array}$ & B \\
\hline 15 & Dull; some bleaching & $\begin{array}{l}\text { Opalescent cornea; } \\
\text { sunken; excessive } \\
\text { mucus }\end{array}$ & $\begin{array}{l}\text { Spoiled odor; dark red } \\
\text { color }\end{array}$ & $\begin{array}{l}\text { Whitish with slight yel- } \\
\text { low stain }\end{array}$ & Thick;Milky & C \\
\hline
\end{tabular}

Table 3: Sensory assessment of trout stored at $0-2^{\circ} \mathrm{C}$.

$\mathrm{N} 100 \mathrm{~g}^{-1}$ and high TVBN production was generally correlated with high TMA production. In this study, even with low TMA levels, high TVBN values of $31.25 \mathrm{mg} \mathrm{N} 100 \mathrm{~g}^{-1}$ were obtained and this may be attributed to ammonia production.

$\mathrm{pH}$ values for whole ungutted trout samples increased with storage time from an initial value of 6.74 (Table 2) indicating bacterial growth and production of volatile basic compounds such as ammonia by fish spoilage bacteria. Increase in $\mathrm{pH}$ due to accumulation of alkaline compounds through autolytic activities and microbial metabolism has been reported in earlier studies [65,73,74]. Many microbes including Pseudomonas produce ammonia during amino acid metabolism.

Changes in PV, TBA and FFA for whole ungutted trout stored at $0-2^{\circ} \mathrm{C}$ during the 15 -day storage are shown in Table 2. PV and TBA are indices to measure the first and second stages of oxidative rancidity respectively. PV measures peroxides and hydroperoxides and a value of above $10-20$ is an indication of rancidity [75]. In this study PV showed fluctuations during the chilled storage, but the values were very low to cause rancidity or off flavour at any point of time during the study.

TBA values for whole ungutted trout samples increased steadily from an initial value of $4.9 \pm 0.3 \mu \mathrm{g} \mathrm{MA} / \mathrm{g}$ and reached a value of 14.1 $\mu \mathrm{g} \mathrm{MA} / \mathrm{g}$ on day 9 when fish retained high quality as per EC grade and the value was $16.6 \mu \mathrm{g} \mathrm{MA} / \mathrm{g}$ when fish spoiled on day 15 (Table 2). The results of this study confirmed the earlier finding that oxidative rancidity remained relatively low in aquacultured whole ungutted trout throughout the entire period of storage in ice and oxidative rancidity indices viz., PV and TBA are poor indicators of quality since lipids in trout are relatively stable during chilled storage[12]. The low level of lipid oxidation products suggest that whole ungutted rainbow trout stored at 0-2 $0 \mathrm{C}$ has some intrinsic factors to prevent oxidation. The lipids were found to better stable in whole than in gutted or filleted trout possibly due to the fact that it is harder for oxygen to penetrate into whole fish and there may be a higher accumulation of proteolysis products, acting as antioxidants, with time of storage [76]. Because the rainbow trout studied showed no increased lipid oxidation during the first week of storage (a decrease in PV relative to the initial level being observed), it may be suggested that the muscle tissue of rainbow trout, particularly in the whole fish, was predominantly a site of antioxidant over pro-oxidant activity at that time [77]. Fifteen days in chilled conditions has accumulated only $4 \%$ of FFA which indicates that rainbow trout has very low level of lipase activity during chilled storage.

Changes in sensory attributes of the whole ungutted trout in chilled storage were given in descriptive terms as recorded by given by the panelists (Table 3). Whole ungutted trout was in excellent condition up to six days in chilled conditions and the high quality was retained for nine days. The fish was still considered to be of good quality and fit for sale between 12-14 days of chilled storage. The fish samples were spoiled on 15 th day.

The overall acceptability scores for whole ungutted trout remained in the range of seven points up to nine days indicating that there was no significant loss of sensory attributes viz., odour, taste and texture. 
Citation: Ninan G, Lalitha KV, Zynudheen AA, Joseph J (2011) Effect of Chilling on Microbiological, Biochemical and Sensory Attributes of Whole Aquacultured Rainbow Trout (Oncorhynchus mykiss Walbaum, 1792). J Aquac Res Development S5:001. doi:10.4172/2155-9546.S5-001

Page 6 of 8

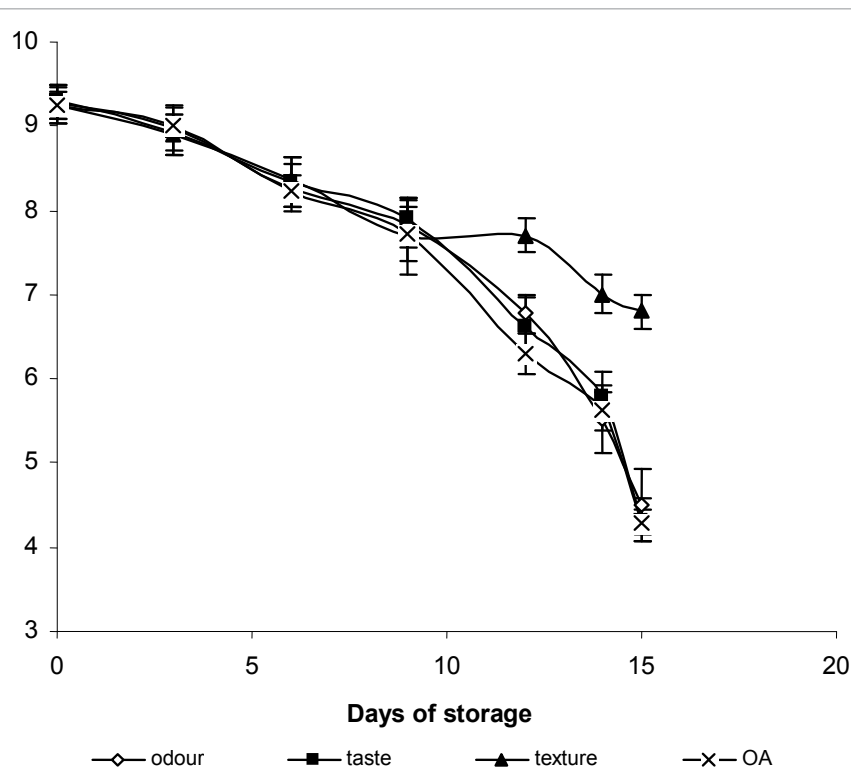

Figure 4: Changes in sensory score in trout stored at $0-2^{\circ} \mathrm{C}$.

The limit of acceptability for odour and taste was reached by the 14 th day in chilled condition (Figure 4). However the chilled fish retained the texture with slight changes and the limit of acceptability was not reached for this attribute during the entire chilled storage period.

The sensory changes observed in rainbow trout during storage in ice were in agreement with the descriptions presented by other authors $[11,66,78,79]$. The quality deterioration in trout was correlated with reduced tastefulness of the cooked fish. The reduction in tastefulness was caused primarily probably by nucleotide decomposition $[80,81]$. Based on the sensory score, trout had a shelf life of 12-14 days in ice.

Change in colour parameters of mince prepared from chill stored rainbow trout is given in Table 4. During chill storage there is a gradual increase in $L^{*}$ value (Lightness) with a corresponding decrease in $a^{*}$ (red) value. The $\mathrm{b}^{\star}$ (yellowness) increased during this period. The instrumental colour values correlated well with the sensory observation of flesh given in Table1. Fresh sample (0 day) has pinkish white flesh which progressively turned paler during storage and has yellow stained white colour at the end of storage period. This finding indicated that freshness of trout, in relation to sensory analysis, was lost after total aerobic bacterial count reached limit count.

\section{Conclusion}

The results of the study indicate that the shelf life of whole gutted trout stored in ice as determined by the chemical and microbiological quality is 9-11 days. The whole ungutted rainbow trout stored in ice remained in excellent condition up to six days and retained high quality up to nine days. Based on sensory score, trout had a shelf life of 12-14 days in ice. The results obtained in the present study for trout tend to confirm the earlier observations that TMA, PV and TBA are of questionable use as quality indices. TVBN values exceeded the limit of acceptability when fish had a stale order and microbial count exceeded $3 \times 106 \mathrm{cfu} \mathrm{g}^{-1}$ indicating that TVBN may be useful as a measure of degree of freshness. Detailed sensory evaluation is the effective and practical method to assess the freshness of chill stored whole ungutted rainbow trout.

\begin{tabular}{|l|l|l|l|l|l|}
\hline Days & $\mathrm{L}^{*}$ & $\mathrm{a}^{*}$ & $\mathrm{~b}^{*}$ & Hue & Chroma \\
\hline 0 & $47.26 \pm .05$ & $2.41 \pm 0.15$ & $9.32 \pm 0.07$ & $75.49 \pm 0.97$ & $9.63 \pm 0.03$ \\
\hline 3 & $47.72 \pm 0.14$ & $2.23 \pm 0.03$ & $9.82 \pm 0.02$ & $77.19 \pm 0.16$ & $10.07 \pm 0.03$ \\
\hline 6 & $48.52 \pm 0.03$ & $2.09 \pm 0.02$ & $\begin{array}{l}10.23 \pm \\
0.04\end{array}$ & $78.42 \pm 0.09$ & $10.44 \pm 0.04$ \\
\hline 9 & $49.75 \pm 0.23$ & $1.95 \pm 0.18$ & $9.84 \pm 0.64$ & $78.79 \pm 0.37$ & $\begin{array}{l}10.04 \pm \\
0.66\end{array}$ \\
\hline 12 & $50.89 \pm 0.56$ & $1.51 \pm 0.07$ & $10.42 \pm 0.19$ & $81.77 \pm 0.37$ & $10.53 \pm 0.19$ \\
\hline 14 & $53.02 \pm 0.19$ & $1.25 \pm 0.03$ & $\begin{array}{l}10.61 \pm \\
0.09\end{array}$ & $83.29 \pm 0.22$ & $10.68 \pm 0.09$ \\
\hline 15 & $55.65 \pm 0.45$ & $1.28 \pm 0.07$ & $10.79 \pm 0.11$ & $83.23 \pm 0.32$ & $10.86 \pm 0.12$ \\
\hline
\end{tabular}

$L^{*}$ value (Lightness), $a^{*}$ (red) value, $b^{*}$ (yellowness)

Table 4: Changes in colour parameters of the mince of trout stored at $0-2^{\circ} \mathrm{C}(\mathrm{n}=$ $3 \times 2)$

\section{Acknowledgements}

The authors are thankful to the Director, Central Institute of Fisheries Technology, for according permission to publish the paper. The assistance rendered by M/s Tata Tea Ltd, Munnar, Kerala and the High Range Angling Association in the collection of trout samples is gratefully acknowledged.

\section{References}

1. Sehgal KL (1999) Fish and fisheries at higher altitudes: Asia FAO Fisheries Technical Paper. No.385. FAO, Rome. 304p.

2. Horsley RW (1973) The bacterial flora of the Atlantic salmon (Salmo salar L) in relation to its environment. J App Bacteriol 36: 377-386.

3. Ozogul Y, Ahmad JI, Hole M, Ozogul F, Deguara S (2006) The effects of partial replacement of fish meal by vegetable protein sources in the diet of rainbow trout (Onchorynchus mykiss) on post mortem spoilage of fillets. Food Chem 96: 549-561.

4. Hernandez MD, López MB, Alvarez A, Ferrandini E, Garcia B, et al. (2009) Sensory, physical, chemical and microbiological changes in aquacultured meagre (Argyrosomus regius) fillets during ice storage. Food Chem 114: $237-$ 245

5. Gram L, Huss H (1996) Microbiological Spoilage of Fish and Fish Products. Int J Food Microbiol 33: 121-137.

6. Randell K, Hattula T, Ahvenainen R (1997) Effect of packaging method on the quality of rainbow trout and Baltic herring fillets. Lebensm. Wiss Technol 30 56-61.

7. Lyhs U, Hatakka M, Maki-Petays N, Korkeala H (1998) Prevalence of Listeria monocytogenes in Finnish vacuum-packaged fishery products In: Proc. 4th World Congress Foodborne Infections and Intoxications, 7 - 12 June 1998 Berlin. 2: 1051-1052.

8. Mills A (2001) Handling and Processing Rainbow Trout Torry Advisory Note no. 74 Ministry of Agriculture, Fisheries and Food, Torry Research Station, UK.8p.

9. Gimenez B, Roncales P, Beltran JA (2002) Modified atmosphere packaging of filleted rainbow trout. J Sci Food Agric 84: 1154-1159.

10. Arashisar S, Hisar O, Kaya M, Yanik T (2004) Effect of modified atmosphere and vacuum packaging on microbiological and chemical properties of rainbow trout (Oncorynchus mykiss) fillets. Int J Food Microbiol 97: 209-214.

11. Kolakowska A, Zienkowicz L, Domiszewski Z, Bienkiewicz G (2006) Lipid changes and sensory quality of whole- and gutted rainbow trout during storage in ice. Acta Ichthyol Piscat 36: 39-47.

12. Chytiri S, Chouliara I, Savvaidis IN, Kontominas MG (2004) Microbiological,chemical and sensory assessment of iced whole and filleted aquacultured rainbow trout. Food Microbiol 21 : 157-165.

13. Dawood AA, Roy RN, Williams CS (1986a) Effect of delayed icing on the storage of life of rainbow trout. J Food Tech 21: 159-166.

14. Rodríguez CJ, Besteiro I, Pascual C (1999) Biochemical changes in freshwater rainbow trout (Oncorynchus mykiss) during chilled storage. J Sc Food Agricult 79: $1473-1480$

15. Austin B, Al- Zahrani AMJ (1988) The effect of antimicrobial compounds on the gastrointestinal microflora of rainbow trout, Salmo gairdneri Richardson. J Fishery Biol 33: 1-14. 
Citation: Ninan G, Lalitha KV, Zynudheen AA, Joseph J (2011) Effect of Chilling on Microbiological, Biochemical and Sensory Attributes of Whole Aquacultured Rainbow Trout (Oncorhynchus mykiss Walbaum, 1792). J Aquac Res Development S5:001. doi:10.4172/2155-9546.S5-001

16. AOAC (2000) Official Methods of Analysis (17th ed.), Association of Official Analytical Chemists, Washigton, DC, 1298p

17. Molin G, Ternstrom A (1982) Numerical taxonomy of psychrotrophic pseudomonads. J Gen Microbiol 128: 1249-1264.

18. Mead GC (1985) Enumeration of pseudomonads using cephaloridine-fucidincetrimide agar (CFC). Int J Food Microbiol 2: 21-26.

19. Palumbo SE, Maxino SA, Williams F, Buchanan RL, Thayer DW (1985) Starchampicillin agar for the quantitative detection of Aeromonas hydrophila. App Environ Microbiol 50: 1027-1030

20. Gardner GA (1966) A selective medium for the enumeration of Microbacterium thermosphactum in meat and meat products. J Appl Bacteriol 29: 455-460

21. Mossel DAA (1987) Violet Red Bile Glucose (VRBG) agar. Int J Food Microbiol 5: $280-281$.

22. Gennari M, Campanini R (1991) Isolamento e caratterizzazione di Shewanella putrefaciens da pesce fresco e alterato, carni fresche e alterate, prodotti lattiero- caseari, acqua e suolo. Industrial Alimenteria 30: 965-976, 988.

23. Food and Drug Administration (1998) FDA Bacteriological Analytical Manual. 8th Edition. AOAC International, Gaithersburg, MD, Chapter 12

24. APHA (1998) Standard Methods for the examination of water and waste water , 20th edition, American Public Health Association, Inc, Washington D.C Part 9000-9221: 48-59

25. Dainty RH, Shaw BG, Hardinger CD, Michanie S (1979) The spoilage of vacuum packaged beef by cold tolerant bacteria, In Russell \& R. Fuller, Cold tolerant bacteria in spoilage and the environment New york: Academic press, pp 83-110.

26. Krieg NR, Holt JG (1984) Bergey's Manual of Systematic Bacteriology.vol.1, Baltimore, USA: Williams and Wilkins. $964 \mathrm{p}$

27. Sneath PHA, Mair NS, Sharpe ME, Holt JG (1986) Bergey's Manual of Systematic Bacteriology. vol.2, Baltimore, USA: Williams and Wilkins. 964 p.

28. Kirov SM (2001) Aeromonas and Plesiomonas species. In Doyle M, Beuchat L,Montiville T(Eds.). Food Microbiology: Fundamentals and Frontiers, ASM Press, Washington, D.C, pp 301-327.

29. Brenner DJ, Krieg NR, Staley JT (2004) Bergey's manual of systematic bacteriology, 2nd edn, Vol 2. Springer, USA.

30. Tarladgis BG, Watts BM, Younathan MT, Dugan L (1960) A Distillation Method for the quantitative determination of Malonaldehyde in Rancid Food. J Am Oil Chem Soc 37: 44-48

31. Conway EJ (1962) Determination of Volatile Amines, Microdiffusion Analysis and Volumetric Error 5 th edn, Parch Croskey and Sockwood \& Son Limited, London.

32. Jacobs MB (1958) In: The chemical analysis of foods and food products Kreiger Pub.Co., New York. pp 393 - 394.

33. AOCS (1989) Official Methods of Recommended Practices of American Oil Chemists Society A.O.C.S., Chempaign, USA

34. Howgate P, Johnston A, Whittle KJ (Eds.) (1992) Multilingual Guide to EC Freshness Grades for Fishery Products. Marine Laboratory, Scottish Office of Agriculture, Environment and Fisheries Department, Aberdeen.

35. Commision Internationale de L'Eclairage (CIE) (1986). Colorimetry. 2nd Ed. CIE 434 No. 15.2 CIE, Vienna.

36. Huss HH (1995) Quality and Quality changes in fresh fish. FAO Fisheries Technical Paper No.348, FAO, Rome.

37. Gonzalez-Rodriguez MN, Sanz JJ, Santos JA, Otero A, Garcia-Lopez ML (2001) Bacteriological quality of aquacultured freshwater fish portions in prepackaged trays stored at 3oC. J Food Prot 64: 1399-1404.

38. Savvaidis IN, Skandamis $\mathrm{P}$, Riganakos KA, Panagiotakis N, Kontominas MG (2002) Control of natural microbial flora and Listeria monocytogenes in vacuum-packaged trout at 4 and 10 degrees $\mathrm{C}$ using irradiation. J Food Prot 65: 515-522.

39. Nerantzaki A, Tsiotsias A, Paleologos EK, Savvaidis IN, Bezirtzoglou E, et al. (2005) Effects of ozonation on microbiological, chemical and sensory attributes of vacuum-packaged rainbow trout stored at $4 \pm 0.5 \mathrm{C}$. Eur Food Res Technol 221: 675-683.
40. Ozogul Y, Ozogul F (2002) Degradation Products of Adenine Nucleotide in Rainbow Trout (Oncorhynchus mykiss) Stored in Ice and in Modified Atmosphere Packaging. Turk J Zool 26: 127-130.

41. González CJ, López-Diaz TM, García-Lopez ML, Prieto M, Otero A (1999) Bacterial microflora of wild brown trout (Salmo trutta), wild pike (Esox lucius) and aquacultured rainbow trout (Onchorynchus mykiss). J Food Prot 62: 1270 1277.

42. ICMSF (International Commission on Microbiological Specifications for Foods) (1998) Microorganisms in Foods. 6. Microbial Ecology of Food Commodities. Blackie Academic and Professional, Baltimore.

43. Fik M, K Surowka (2004) Autoproteolysis rate of rainbow trout muscle proteins. Nahrung 48: 104-109.

44. Rezaei M, Hosseini SF (2008) Quality assessment of farmed rainbow trout (Onchorynchus mykiss) during chilled storage. J Food Sci 73: 93-96.

45. Nam IY, Joh K (2007) Rapid detection of virulence factors of Aeromonas isolated from a trout farm by hexaplex-PCR. J Microbiol 45: 297-304.

46. S, Kim S, Oh Y, Lee Y (2000) Characterization of Aeromonas hydrophila Isolated from Rainbow Trouts in Korea. J Microbiol 38: 1-7.

47. Paniagua C, Rivero O, Anguita J, Naharro G (1990) Pathogenicity factors and virulence for rainbow trout (Salmogairdneri) of motile Aeromonas spp. isolated from a river. J Clin Microbiol 28: 350-355.

48. Chacon MR, Figuras MJ, Castro-Escarpulli G, Soler I, Guarro J (2003) Distribution of Virulence genes in clinical and environmentl islates of Aeromonas spp. Antonie van Leeuwenhoek 84: 269-278

49. González CJ, Santos J A, Garcia-Lòpez ML, González N, Otero A (2001) Mesophilic Aeromonads in Wild and Aquacultured Freshwater Fish. J Food Protect 64: 687-691.

50. Merino S, Camprubi S, Tomas J M (1992) Effect of growth temperature on outer membrane components and virulence of Aeromonas hydrophila strains of serotype O: 34 . Infect Immun 60: 4343-4349.

51. Merino S, Rubires X, Knochel S, Tomas JM (1995) Emerging pathogens: Aeromonas spp. Int J Food Microbiol 28: 157-168.

52. PK, Thampuran N, Gopakumar K (1995) Microbial profile of cultured fishes and prawns viz a viz their spoilage and contamination. FAO Fisheries Report No.514 supplement, FAO, Rome, Italy, pp.1-12.

53. Lalitha KV, Surendran PK (2004) Bacterial microflora associated with farmed freshwater Prawn Macrobrachium rosenbergii (de Man) and the aquaculture environment. Aquac Res 35: 629-635.

54. Lalitha KV, Surendran PK (2006) Microbiological changes in farm reared freshwater prawn (Macrobrachium rosenbergii de Man) in ice. Food Control 17: 802-807

55. Holt RA, Rohovec JS, Fryer JL (1993) Bacterial cold-water disease. In: Bacteria diseases of fish (V. Inglis, R. J. Roberts and N. R. Bromage, Ed), Blackwell Scientific Publications, London, pp 3-22.

56. Nematollahi A, Decostere A, Pasmans F, Haesebrouck F (2003) Flavobacterium psychrophilum infections in salmonid fish. J Fish Dis 26: 563-574

57. Surendran PK, Joseph J, Shenoy AV, Perigreen PA, Mahadeva Iyer K, et al (1989) Studies on spoilage of commercially important Tropical fishes under iced storage. Fish Res 7: 1-9

58. Akhtar, N (1994) Fish composition and balance in population in Rawal Dam reservoir of Pakistan. Pakistan Journal of Zoology 61:111-118.

59. Unlusayin M, Kaleli S, Gulyavuz H (2001) The determination of flesh productivity and protein components of some fish species after hot smoking. J Sci Food Agri 81: $661-664$.

60. Gokoglu N, YerlikayaP, Cengiz E (2004) Effects of cooking methods on the proximate composition and mineral contents of rainbow trout (Oncorhynchus mykiss). Food Chemistry 84: 19-22.

61. CJ, Besteiro I, Pascual C (1999) Biochemical changes in freshwater rainbow trout (Oncorhynchus mykiss) during chilled storage. J Sci Food Agri 79: 14731480.

62. Kyrana VR, Lougovois VP, Valsamis DS (1997) Assessment of shelf-life of maricultured gilthead sea bream (Sparus aurata)stored in ice. Int J Food Sci and Technol 32: 339-347. 
Citation: Ninan G, Lalitha KV, Zynudheen AA, Joseph J (2011) Effect of Chilling on Microbiological, Biochemical and Sensory Attributes of Whole Aquacultured Rainbow Trout (Oncorhynchus mykiss Walbaum, 1792). J Aquac Res Development S5:001. doi:10.4172/2155-9546.S5-001

Page 8 of 8

63. Tejada M, Huidobro A (2002) Quality of farmed gilthead seabream (Sparus aurata) during ice storage related to the slaughter method and gutting. Eur Food Res Technol 215: 1-7.

64. Goulas AE, Kontominas MG (2007) Combined effect of light salting, modified atmosphere packaging and oregano essential oil on the shelf-life of sea bream (Sparus aurata): biochemical and sensory attributes. Food Chem 100: 287 296.

65. Lalitha KV, Sonaji ER, Manju S, Jose L, Gopal TK, et al. (2005) Microbiological and biochemical changes in pearl spot (Etroplus suratensis Bloch) stored under modified atmospheres. J Appl Microbiol 99: 1222-1228.

66. Sikorski ZE, Kolakowska A, Burt JR (1990) Postharvest biochemical and microbial changes. In: Sikorski Z.E. (ed.) Seafood: resources, nutritional composition and preservation. CRC Press, Boca Raton, pp 55-76.

67. Dalgaard P, Gram L, Huss HH (1993) Spoilage and shelf life of cod fillets packed in vacuum or modified atmospheres. Int J Food Microbiol 19: 283-294.

68. ME (1963) Analytical methods. In: Industrial Fishery Technology Krieger Publishing Co., Inc., New York, 367 p.

69. Dalgaard P (2000) Fresh and lightly preserved seafood. In: Man,C.M.D. and A.A. Jones (eds) Shelf-Life Evaluation of Foods. Aspen Publishers Inc., London, UK. pp. 110-139.

70. Katikou P, Ambrosiadis L, Georgantellis D, Koidis P, Georgakis AS (2007) Effect of lactobacillus cultures on microbiological, chemical and odour changes during storage of rainbow trout fillets. J Sci Food Agric 87: 477-484

71. Dawood AA, Roy RN, Williams CS (1986b) Quality of rainbow trout chilledstored after post-catch holding. J Sci Food Agric 37: 421-427.

72. Stohr V, Joffraud JJ, Cardinal M, Leroi F (2001) Spoilage potential and sensory profile associated with bacteria isolated from cold-smoked salmon. Food Res Int 34: $797-806$.

73. Ruiz-Capillas C, Moral A (2001) Correlation between biochemical and sensory quality indices in hake stored in ice. Food Res Int 34: 441- 447

74. Pons-Sanchez-Cascado S, Veciana-Nogues MT, Bover-Cid S, Marine-Font A Vidal-Carou MC (2006) Use of volatile and non-volatile amines to evaluate the freshness of anchovies stored in ice. J Sci Food Agric 86: 699-705.

75. Connel JJ (1995) Control of fish quality, 4th Ed. London: Fishing News Books Limited.

76. Je JY, Park PJ, Kim SK (2005) Antioxidant activity of a peptide isolated from Alaska pollack (Theragra chalcogramma) frame protein hydrolysate. Food Res Int 38: 45-50.

77. Han TJ, Liston J (1989) Lipid peroxidation protection factors in rainbow trout (Salmo gairdnerii) muscle cytosol. J Food Sci 54: 809-813.

78. Gould E, Peters JA (1971) On the testing the freshness of frozen fish. Fishing News (Books), London.

79. Olafsdottir G, Martinsdottir E, Oehlenschlager J, Dalgaard P, Jensen B, et al (1999) Methods to evaluate fish freshness in research and industry. Tr Fd Sc \& Tech 8: $258-265$.

80. Huss HH (1988) Fresh fish quality and quality changes. FAO Fisheries Series, No. 29, FAO, Rome.

81. Regenstein JM (1996) Assuring the freshness and quality of aquacultured fish In: Froid et al., Aquaculture Refrigeration and Aquaculture, 20-22 March 1996 Bordeaux, France, pp. 343-362.

This article was originally published in a special issue, Fisheries and Aquaculture Advancement handled by Editor(s). Dr. Hiran Dutta, Kent state University, USA. 